\title{
The Pathogenesis of Hashimoto's Thyroiditis: Further Developments in our Understanding
}

Authors

Affiliations

\section{R. A. Ajjan ${ }^{1}$, A. P. Weetman}

${ }^{1}$ Division of Cardiovascular and Diabetes Research, Leeds Institute of Cardiovascular and Metabolic Medicine, University of Leeds, Leeds, UK

${ }^{2}$ Department of Human Metabolism, University of Sheffield, Sheffield, UK
Key words

autoimmune

hypothyroidism

- immunogenetics

- environmental factors

- immunopathogenesis

thyroid autoantibodies

received 03.02 .2015

accepted 04.03 .2015

\section{Bibliography}

DOI http://dx.doi.org/

10.1055/s-0035-1548832

Published online:

April 16, 2015

Horm Metab Res 2015;

47: 702-710

(c) Georg Thieme Verlag KG Stuttgart · New York

ISSN 0018-5043

\section{Correspondence}

\section{Prof. A. P. Weetman}

Faculty of Medicine, Dentistry and Health

Barber House

387 Glossop Road

Sheffield S10 2HQ

United Kingdom

Tel.: + 44/114/222 8710

Fax: $+44 / 113 / 3437738$

a.p.weetman@sheffield.ac.uk

\section{Abstract}

$\nabla$

Hashimoto's thyroiditis (HT) is part of a spectrum of thyroid autoimmune conditions and this review provides an update on the latest developments in the field. HT has a genetic predisposition with a number of immune-related and thyroid-specific genes conferring disease susceptibility. However, disentangling genes with protective and predisposing effect is a complex process that requires further work. The recent increase in the incidence of HT implicates environmental factors in disease pathogenesis including improved hygiene, increased dietary iodine intake, new treatment modalities and chemical agents. Additional unmodifiable predisposing factors include stress, climate, age and gender. Both cellular and humoral immunity play a role in HT pathogenesis. Defects in T regulatory cells and increased activation of follicular helper $\mathrm{T}$

\section{Introduction}

$\checkmark$

Hashimoto's thyroiditis (HT) sensu stricto is the occurrence of what was originally termed struma lymphomatosa, translated into English as lymphadenoid goitre, by Hakaru Hashimoto over 100 years ago $[1,2]$. These early observations were obviously made at a time when thyroid function testing was unavailable, immunology was nascent and the disease was judged to be rare. As is now clear, HT is part of a spectrum of autoimmune diseases which affect the thyroid, ranging from typically self-limiting forms such as focal, silent and juvenile thyroiditis through to atrophic thyroiditis presenting as hypothyroidism without goitre. There has been considerable speculation as to the exact relationship between these entities; suffice here to say that good ultrasound evidence shows that there is a unimodal distribution of thyroid size in hypothyroidism, which cells may have a role in disease initiation/perpetuation. Infiltrating lymphocytes can be directly cytotoxic to thyroid follicular cells (TFC) or may affect cell viability/function indirectly through cytokine production, which alters TFC integrity and modulates their metabolic and immune function. Thyroid peroxidase and thyroglobulin antibodies are present in the majority of HT patients and help with management decisions. Antibodies against the sodium iodide symporter and pendrin are present in a minority with little known about their clinical relevance. In addition to immune cells, recent work has identified DNA fragments, generated following cell death, and micro RNA as potential factors in HT pathogenesis. Despite the large number of studies, the mechanistic pathways in HT are still not fully understood and further work is required to enhance our knowledge and identify novel preventative and therapeutic clinical targets.

indicates that HT is likely to be an extreme in this distribution and does not constitute a separate disease entity, although there are different clinical presentations across the distribution curve [3]. And while immunological techniques described below are defining discrete types of disease, such as the IgG4-related variant, for the purposes of this review we will not distinguish HT from other forms of autommune hypothyroidism except where indicated; this pragmatic approach is also necessary because of the rather loose definition that investigators apply to patients. There have been several recent reviews of this subject, in large part occasioned by the centenary of Hashimoto's discovery [4-7]. We therefore have mainly concentrated on papers since 2010, to bring readers an update on recent developments in the field, focussing firstly on predisposing factors and then on the pathogenic mechanisms responsible for tissue damage. 


\section{Genetic Susceptibility}

\section{$\nabla$}

Recent studies on susceptibility to HT have revealed several new aspects of interest. Using the diagnosis data set for military personnel in the USA, it has been established that HT has the highest incidence in white individuals, and is lowest in black and Asian/Pacific Islander individuals [8]. This difference may be the result of genetic and/or environmental factors, yet the pattern is reversed in Graves' disease (GD), which shares some of these susceptibility factors; unravelling what causes these striking ethnic patterns would be a novel approach to understanding susceptibility. A related phenomenon is the differential clustering of additional autoimmune diseases that are associated with GD and HT; HT is markedly more associated with such disorders, especially Addison's disease and type 1 diabetes mellitus [9]. Again this could be the result of genetic and/or environmental factors.

A genetic susceptibility to the inheritance of thyroid autoantibody patterns has been established and the familial aggregation of thyroid autoantibodies is clearly shown in a recent study of multiplex Han Chinese families [10]. Work on monozygotic twins discordant for HT has demonstrated that in the absence of thyroid disease, these individuals nonetheless share a higher than expected propensity to develop thyroid peroxidase (TPO) autoantibodies that recognise one of the 2 main epitopes on this autoantigen [11]. The technique of regression of offspring on mid-parent screening has been used to show that IgG4 subclass thyroid autoantibodies display heritability, albeit only in those with high levels of both TPO and thyroglobulin (TG) antibodies, and this could allow the development of novel screening methods to predict disease evolution [12].

Whilst more attention has been paid to GD with regard to finding the responsible genes, there are an increasing number of attempts to investigate HT using either the candidate gene approach or genome wide association studies (GWAS). These genes can be broadly classified into those which control the immune response and those which are thyroid-specific and thus increase target organ risk. Amongst the first group, further work has been done on the archetypal immune response genes encoded on the HLA complex, which has revealed that $H L A-B * 46: 01$ confers an increased risk of HT developing in Han Chinese children, using a combined case-control and familybased approach [13]. Using a sample of 444 Japanese HT patients, $H L A-A^{*} 02: 07$ and HLA-DRB4 conferred susceptibility and the HLA-A *33:03-C * 14:03-B * 44:03-DRB1 * 13:02-DQB1 * 06:04$D P B 1^{*}$ 04:01 haplotype conferred protection [14]. A smaller scale case control study of 75 Caucasian HT patients found that HLA-A2 did not confer protection against disease, in contrast to GD [15]. These results highlight the complexities of studying even a single set of genes, with both protective and susceptibility actions that may be in part epistatic [14] and which have ethnically restricted effects.

The involvement in autoimmunity of many other immunoregulatory genes besides those in the HLA complex is now clear; amongst these, single nucleotide polymorphisms (SNPs) in CTLA-4, PTPN22, CD40 and IL2R are known to have some effect in both GD and HT and more information has come from metaanalyses. A recent meta-analysis of the A49G SNP in CTLA-4 has shown that this increases the risk of HT in both East Asian and white individuals, with odds ratios of 1.48 and 1.27 , respectively [16]. By contrast, a meta-analysis of studies on the PTPN22 C1858T polymorphism found no association with HT, although this was associated with GD [17]. The situation is similar with the $C D 40 \mathrm{C} / \mathrm{T} 1$ polymorphism, which is associated with susceptibility to GD but not HT [18]. The latter study raises the question of how to classify controls with high levels of thyroid autoantibodies; we do not agree with the conclusion that these individuals should be classified as having HT, especially given the independent heredity of such antibodies.

Polymorphisms in the genes which encode or regulate cytokines constitute another obvious set of candidates for testing, although results to date have been inconclusive. The largest study recently (of 202 Tunisian HT patients) found an association with an IL1RN VNTR polymorphism [19] and a study with a similarly sized population of 182 Chinese HT patients has shown that the rs763780 polymorphism in IL17F, but not the 3 studied SNPs in the IL17A gene, may also be associated with HT [20]. In a small scale study that was however replicated across 3 separate populations, the rs6887695 IL12B variant was more frequent in GD and less frequent in HT, compared to controls [21]. Another study of 108 Japanese HT patients, subdivided into mild and severe forms, has identified a borderline association with a SNP in IL6 in severe HT, but this study is compromised by the multiple uncorrected comparisons and small size [22]. The same group, using a similar sized sample, have also reported associations of a SNP in GITR with mild rather than severe HT; this finding is somewhat supported by the identification of a higher proportion of glucocorticoid-induced tumour necrosis factorreceptor (GITR)-expressing T cells in HT individuals with the GG genotype of the SNP [23]. Such T cells may have regulatory and effector functions. The STAT family of proteins are transcription activators that regulate a number of immunoregulatory pathways, including cytokine signalling. Using a population of 250 Chinese HT patients, a SNP in STAT3 was found to be associated with HT, as well as GD [24].

With respect to thyroid-specific genes, it has been established that polymorphisms in the gene encoding the TSH receptor confer susceptibility to GD but not HT, whereas polymorphisms in $T G$ appear to confer more general susceptibility to thyroid autoimmunity. Five polymorphisms in $T G$ have been associated with GD rather than HT in a recent Japanese cohort of patients, leading to identification of a putative protective haplotype for the former [25]. Attempts have also been made to understand how polymorphisms in TG may be implicated in pathogenesis; at least one possibility is that a disease-associated SNP in the promoter confers increased activity, but only in the presence of interferon, which is clearly of interest given the effects of this agent therapeutically, as described below [26]. Although not thyroid-specific in tissue location, selenoproteins (SEP) are central to thyroid hormone deiodination and selenium itself may have a role in predisposition as a dietary environmental factor (see below). In a study of 481 HT patients from Portugal, there was a significant association with a promoter SNP in SEPS1, giving an odds ratio of 2.24 [27]. Of the candidate gene studies just mentioned, this is by far the largest and the most likely therefore to have sufficient power to be reliable, but as with all the others, replication is required, a task compounded if consideration is taken of possible heterogeneity conferred by sex, ethnic background or disease subtype. As with other polymorphisms that may be relevant, epistatic effects and an interaction with environmental factors, in this case selenium intake, increase the complexity of analysis.

GWAS offers a hypothesis-free approach to understanding disease susceptibility which allows the discovery of novel path- 
ways, although these studies have their own particular issues [28]. One good example is the uncovering of a new set of genetic markers, including polymorphism in MAGI3, which are associated with an increased risk of progression from TPO antibody positivity to hypothyroidism [29]. Using a custom-made SNP array to analyse over 100000 common SNPs in 462 British HT patients, 4 definite new associations were found ( 7 when the sample was added to a larger group of Graves' patients); these loci have been associated with other autoimmune disorders [30]. Another refinement has been to undertake detailed fine mapping of a locus previously linked to HT on chromosome 10q; this revealed an association with $A R I D 5 B$, which has also been associated with rheumatoid arthritis and GD in Japanese patients [31]. A summary of current studies is provided in $\bullet$ Table 1. It is clear that the genetics of HT are much more complex than previously thought and that a detailed understanding will only be gained slowly through adequately powered and replicated datasets. Association is not causation, and more work is needed to understand how certain SNPs exert their effect, how they might interact with one another through epistasis and how they also interact with environmental factors.

\section{Environmental Contribution}

$\nabla$

The importance of a direct or epigenetic role for environmental factors in the pathogenesis of HT is clear from the recent changes in epidemiology. A detailed analysis of the pathological specimens at the Johns Hopkins Hospital over the last century has revealed that HT was rare before the 1950s, but it is now one of the commonest autoimmune disorders [32]. A survey from Austria of thyroidectomy specimens from 1979 to 2009 supports these data by showing an increase in HT over the last 31 years [33]. Such rapid changes clearly cannot be the result of any shift in genetic susceptibility, but a number of obvious environmental suspects have changed with sufficient rapidity to be credible candidates for this increase. Foremost amongst these are (i) the shift towards a more hygienic environment, which may skew the developing immune system away from microbial responses towards the development of allergic and autoimmune diseases, including those against the thyroid (reviewed in [34]), and (ii) an increase in dietary iodine. Many previous studies have demonstrated that excessive dietary iodine can precipitate or exacerbate HT in susceptible individuals and this information continues to be gathered. For instance a 15 year follow-up of the Pescopagano survey, which has monitored the effects of voluntary iodine prophylaxis in an iodine-deficient part of Italy, has shown that the prevalence of thyroid autoantibodies almost doubled and HT quadrupled during this time [35].

There are also epidemiological data suggesting that inadequate dietary selenium intake may exacerbate HT; selenium intake is geographically variable and in Europe has fallen by $50 \%$ over the last 3 decades. However, a recent meta-analysis of trials of selenium supplementation in HT showed no clear beneficial effect on thyroid morphology, although TPO autoantibody levels do fall over 3 months [36]. A Cochrane Systematic Review has come to much the same conclusion, with evidence that current studies are inadequate to assess any benefit [37]. The CATALYST trial is now under way, which may answer questions about a role for selenium in thyroid autoimmune disease decisively [38]. A final dietary component which has created interest is vitamin $D$, albeit with a major contribution to serum levels being due to sun
Table 1 Summary of the genetic factors associated with Hashimoto's thyroiditis.

\begin{tabular}{|c|c|}
\hline Gene & Comments \\
\hline HLA & $\begin{array}{l}\text { Confirmed; various haplotypes associated, } \\
\text { ethnically variable, some protective }\end{array}$ \\
\hline CTLA-4 & Confirmed \\
\hline Cytokine genes & $\begin{array}{l}\text { Multiple small studies of various genes; } \\
\text { need confirmation and replication }\end{array}$ \\
\hline $\begin{array}{l}\text { GITR (Glucocorticoid- } \\
\text { induced tumour necrosis } \\
\text { factor-receptor) }\end{array}$ & $\begin{array}{l}\text { Single study; needs confirmation and } \\
\text { replication }\end{array}$ \\
\hline STAT3 (STAT family) & $\begin{array}{l}\text { Single study; needs confirmation and } \\
\text { replication }\end{array}$ \\
\hline$T G$ & $\begin{array}{l}\text { Best evidence for association is with Graves' } \\
\text { disease; may be associated with interferon- } \\
\text { induced HT }\end{array}$ \\
\hline SEPS1 (selenoprotein S) & $\begin{array}{l}\text { Single study; needs confirmation and } \\
\text { replication }\end{array}$ \\
\hline MAGI3 & $\begin{array}{l}\text { Strong evidence from GWAS that this plus } \\
\text { other markers are associated with progres- } \\
\text { sion from TPO autoantibody positivity to HT }\end{array}$ \\
\hline ARID5B & $\begin{array}{l}\text { Strong evidence from fine mapping studies; } \\
\text { needs replication in other populations }\end{array}$ \\
\hline $\begin{array}{l}\text { LPP, BACH2 plus } 2 \text { other } \\
\text { loci on } 2 \mathrm{p} 25.1 \text { and } 11 \mathrm{q} 21\end{array}$ & $\begin{array}{l}\text { Strong evidence from GWAS; needs replica- } \\
\text { tion in other populations }\end{array}$ \\
\hline
\end{tabular}

exposure. Although there is some evidence of lower serum vitamin D levels in individuals with HT, these changes may be the result of the metabolic changes of hypothyroidism as much as any aetiological effect, especially as the levels of vitamin D tend to be inversely related to the severity of thyroid dysfunction [39]. A recent review has examined this topic in depth, drawing attention to the limitations of previous studies of vitamin $\mathrm{D}$ in HT, which should be addressed in any future studies [40].

Treatment of patients with novel anticancer treatments, such as cytokines like interferon- $\alpha$ and tyrosine kinase inhibitors, can also induce transient or permanent thyroid dysfunction, including HT; a comprehensive review of this topic has recently been published [41]. To examine the possibility that HT induced by interferon- $\alpha$ could operate through a distinct background genotype, a genomic convergence approach has been used, combining genetic association data with transcriptome analysis of interferon-regulated genes: this led to the identification of 3 putative loci, HLA, SP100/110/140 (on chromosome 2q37.1) and TAP1 (on chromosome 6p21.3), which might be involved [42]. The immune reconstitution syndrome arises during the reconstitution phase after any type of lymphocyte depletion and may result in autoimmunity. When this affects the thyroid, it normally results in GD, as seen with alemtuzumab therapy in multiple sclerosis and the reversal of the lymphopenia of HIV infection with highly active antiretroviral therapy [43]. Alemtuzumab therapy does, however, result in hypothyroidism in $7 \%$ of treated patients and is accompanied by TSH receptor antibodies (presumably functional blockers) in three-quarters of these cases [44]. There is also a single case report of painful HT arising after reconstitution in an HIV-infected individual receiving highly active antiretroviral therapy [45].

Smoking is associated with an increased risk of GD and especially ophthalmopathy, but generally conflicting results have been reported on any association with HT. A detailed population-based, case-control study has recently found that smoking cessation is associated with a sudden and transient rise in HT [46], while a study of individuals genetically at risk of HT has 
Table 2 Summary of the environmental factors associated with Hashimoto's thyroiditis.

\begin{tabular}{|c|c|}
\hline Factor & Comments \\
\hline Hygienic environment & $\begin{array}{l}\text { Modest epidemiological evidence in } \mathrm{HT} \text { and other in other disorders; mechanism is via skewing of the } \\
\text { immune response towards allergy and autoimmunity }\end{array}$ \\
\hline Selenium deficiency & Modest epidemiological evidence but trials of supplementation inconclusive \\
\hline Vitamin D deficiency & Weak epidemiological evidence; may be the result of hypothyroidism per se \\
\hline $\begin{array}{l}\text { Drugs (cytokines, especially interferon- } \alpha \text {, possibly } \\
\text { tyrosine kinase inhibitors, alemtuzumab) }\end{array}$ & Strong evidence; may operate against distinctive genetic background \\
\hline Smoking & Strong evidence for a protective effect; mechanism unclear \\
\hline Alcohol & Strong evidence for a protective effect; mechanism unclear \\
\hline Infection & $\begin{array}{l}\text { Some cases following subacute thyroiditis may be autoimmune but so far unresolved; association with } \\
\text { HHV- } 6 \text { postulated; Yersinia infection has been proposed as a trigger for thyroid immunity but recent } \\
\text { work failed to find convincing evidence to support this concept }\end{array}$ \\
\hline Environmental toxins & Weak epidemiological evidence; limited number of studies so far \\
\hline Irradiation & Modest epidemiological evidence after radioactive fallout or therapeutic neck irradiation \\
\hline
\end{tabular}

shown that progression to overt hypothyroidism is less common in current smokers [47]. Moderate alcohol consumption also turns out to be protective, based on similar types of analysis $[48,49]$, and this is a feature shared with other autoimmune disorders like rheumatoid arthritis. However, the exact immunological basis for these protective effects of smoking and drinking remain to be elucidated.

Infection has for decades been examined as a possible aetiological factor in thyroid autoimmunity. There is evidence that hepatitis $C$ virus may precipitate HT, and permanent hypothyroidism occurs in around $15 \%$ of patients who have had subacute viral thyroiditis; some of these may have an autoimmune basis. Attempts to find viruses in thyroid material in HT have generally failed to be replicated. A recent such candidate is HHV-6 which appears to be active rather than latent when detected in patient with HT and shows tropism for thyroid follicular cells (TFC); these studies used relatively small numbers of patients and controls (62 in total) and clearly more work is needed before drawing any conclusions [50]. Another frequently studied candidate is Yersinia infection which has been associated in some studies with the development of Graves' disease in particular. A recent prospective study of 790 relatives of probands at risk of thyroid autoimmunity found no evidence to support a role for Yersinia in the development of thyroid antibodies over a 4 year period [51]. Much less attention has been paid to environmental toxins as agents that could explain the rapid change in prevalence of HT but 2 recent epidemiological studies, one showing an increase in HT in those living near a petrochemical complex, and another showing an increase in hypothyroidism (HT not specifically identified) in those exposed to pesticides, show the potential of such compounds [52,53]. A summary of the environmental factors associated with HT is shown in $\bullet$ Table 2.

\section{Existential Factors}

\section{$\nabla$}

As well as the susceptibility conferred by genes and the environment, another set of factors influence the predisposition to thyroid disease; we have labelled these as existential [5], in that they are an intrinsic and unavoidable part of human existence. Thus, getting older increases the risk of HT, until the extremes of old age, and being female is the biggest risk factor currently known, as women develop HT up to 10 times more frequently than men. This strong female association remains unexplained although our hunch is that sex steroids have the critical role, as there is compelling evidence for such effects in animal models of many types of autoimmunity [54]. Alternative explanations include skewed $\mathrm{X}$ chromosome inactivation (away from the expected 50:50 parent of origin ratio) and foetal microchimerism [55]. A recent survey of 490 patients with HT found no significant difference in the inactivation of $\mathrm{X}$ chromosomes from normal, but when combined with 4 other studies in a metaanalysis, results just reached significance, suggesting that skewing may have some role $(\mathrm{p}<0.03)$ [56]. Results were much more convincing for GD. A small study of 7 HT patients and 4 Graves' patients has found a significantly higher number of circulating foetal lymphocytes than in 10 healthy controls, but there was also a significantly higher number in the Graves' patients compared to HT patients [57].

If microchimerism is important, it would seem reasonable to expect that HT would be more frequent in women with a higher number of pregnancies. Advancing parity has been associated with an increased risk of becoming TPO autoantibody-positive [58], although this study did not establish whether this was accompanied by HT itself. A survey of 4.6 million Danes for whom childbirth records were available has looked at hospitalisation records and found a slight overall increase in autoimmune diseases in those who had been pregnant, compared to women without children, with a relative risk of 1.04 [59]. There was a possible specific association with HT with a relative risk of 1.11 (confidence interval 1.00-1.24). However, there was only a significant effect in those women who had a single child rather than more children, and the effect was also only significant within 4 years of the birth of the most recent child. Despite the limitations of this study, notably in the ascertainment of cases through hospitalisation with all of its implications, these data indicate to us that any effect of parity (and hence microchimerism) in HT is likely to be rather limited, and the results could just as readily be the result of the well-known post-partum exacerbation of autoimmune thyroiditis, which has its origins in pregnancy-induced alterations in maternal $\mathrm{T}$ cell regulation [60]. Stress has been associated with GD, but there is no evidence that it plays a role in progression to $\mathrm{HT}$ in predisposed individuals [61]. Seasonal effects have been examined, although these may be related to environmental influences such as infection. A recent study found no consistent impact of month of birth in predisposition to HT [62]. Climate may have an effect on predisposition; preliminary findings show that Yakut women living in 
Siberia have a higher than expected prevalence of TPO autoantibodies [63]. The problems of global climate change might therefore include effects on autoimmunity in the future.

\section{Pathogenic Mechanisms}

$\nabla$

Autoimmune thyroid disease is characterised by lymphoid infiltration of the thyroid gland including $\mathrm{T}$ and $\mathrm{B}$ cells. Therefore, both cellular and humoral immunity have a role in the pathogenesis of thyroid autoimmunity.

\section{Cellular immunity}

In autoimmune thyroid disease, $\mathrm{T}$ cells migrate from the periphery into the thyroid gland and actively participate in the autoimmune process. The main cellular pathways that contribute to thyroid destruction are discussed with special focus on latest developments in the field.

\section{Suppressor and regulatory $T$ cell defects}

Suppressor T cells were initially considered to be specific CD8 ${ }^{+}$ cells tasked with inhibiting unwanted immune responses. Early work demonstrated defects in T suppressor cell response to thyroid-specific antigens in autoimmune hypothyroidism, implicating antigen-specific $\mathrm{T}$ suppressor failure in disease pathogenesis [64]. However, findings were criticised for the non-physiological experimental conditions and poor reproducibility of data, casting doubts on the importance of this putative pathway in disease pathogenesis. Some of the functions of suppressor T cells now appear to be those of regulatory $\mathrm{T}$ cells (Tregs), which represent $5-10 \%$ of $C D 4^{+}$cells [65]. Natural Tregs are characterised by high level of CD25 expression as well as expression of transcription factor Foxp3 [66,67]. These cells can dampen the immune response through direct cell to cell contact or indirectly through the production of cytokines such as transforming growth factor (TGF)- $\beta$ and interleukin (IL)-10 [68,69]. Although some studies have shown altered Treg numbers or function in autoimmune thyroid disease (ATD), data have been inconsistent [70-73]. More recent work in 7 GD and 13 HT patients has convincingly demonstrated altered Tregs activity in ATD compared with healthy controls $(n=9)$ or individuals with Down's syndrome $(\mathrm{n}=3)$, a condition with known autoimmune predisposition [74]. Therefore, better understanding of the role of Tregs in the development of thyroid autoimmunity may allow early identification of individuals at risk and may even establish novel therapeutic targets.

Another potential mechanism for the development of HT is decreased sensitivity of $\mathrm{CD}^{+}{ }^{+} \mathrm{T}$ cells to the inhibitory effect of TGF 3 . Using peripheral blood cells, Mirandola and colleagues demonstrated increased protein kinase $C \varepsilon$ expression in $\mathrm{CD}^{+}$ cells, which is responsible for enhanced survival and activity of these cells, secondary to diminished response to TGF $\beta$ inhibition [75].

\section{Follicular helper T cells}

Follicular helper $\mathrm{T}$ cells (Tfh) are a relatively newly identified subset of $T$ helper cells, involved in promoting antigen-specific $B$ cells through the production of IL-21 [76]. These cells express chemokine receptor CXCR5 together with inducible costimulator (ICOS) protein, which represents one of the molecules required for normal cellular function. Using flow cytometry, Zhu and colleagues [77] have shown increased Tfh cells in the peripheral blood of HT patients, which correlated with thyroid-specific antibody levels. Moreover, $\mathrm{CD} 4{ }^{+} \mathrm{CXCR} 5^{+} \mathrm{ICOS}^{\text {high }}$ cells were found in HT thyroid tissue, further implicating these cells in disease pathogenesis.

\section{Cytotoxicity and apoptosis}

$\mathrm{CD}^{+} \mathrm{T}$ cells against both TPO and TG are detected in patients with ATD and mediate gland destruction [78]. However, only $2-3 \%$ of infiltrating $\mathrm{CD} 8{ }^{+}$cells recognise TPO/TG, suggesting the majority of these cells are not thyroid autoantigen-specific. This is not unprecedented as similar data have been reported in type 1 diabetes, another organ-specific autoimmune condition [79].

In addition to cytotoxicity, early reports implicated apoptosis in causing tissue destruction in autoimmune hypothyroidism [80]. Increased expression of the apoptotic molecule Fas is evident on TFC from HT tissue samples, and in vitro studies demonstrate enhanced Fas expression by cytokines but inhibition by TSH [81]. Indeed, the detection of apoptotic cell markers in HT tissue samples, including upregulation of caspase- 3 and decreased expression of bcl-2, further supports the role for apoptosis in disease pathology [82]. More recent work has shown that proinflammatory cytokines are not only responsible for disruption of thyroid hormone synthesis but can mediate apoptosis of thyroid follicular cells through increased oxidative stress [83].

\section{Humoral Immunity \\ $\nabla$}

Thyroid-specific antibody production is a key feature of ATD. We briefly summarise the main thyroid antibodies with the most recent developments in this area.

\section{TPO/TG antibodies and immunoglobulin subclass}

Antibodies against TG and TPO are present in almost all patients with HT [84]. In addition to aiding the diagnosis, TPO antibodies can be used to help predict development of hypothyroidism, particularly when combined with measurement of TSH levels [85]. IgG4-related sclerosing autoimmune disease was first reported more than a decade ago [86] and is characterised by significant organ infiltration of IgG4-positive plasma cells. A number of groups have recently documented a distinct variant of HT where the thyroid gland is infiltrated with IgG4-positive cells. Histologically, IgG4-positive glands showed higher grade fibrosis and more widespread follicular cell degeneration compared with non-IgG4 thyroiditis. Clinical differences were also documented, as IgG4 positivity was associated with male gender, rapid progress of hypothyroidism, more diffuse low echogenicity of the thyroid gland and higher antibody levels $[87,88]$. In support of the relationship between thyroid fibrosis and IgG4, other investigators found Riedel's thyroiditis to be part of systemic IgG4 disease spectrum, although only a small number of patients were analysed and further studies are warranted to confirm these findings [89].

Sodium iodide symporter (NIS) and pendrin antibodies The NIS mediates iodine uptake by the thyroid gland, while pendrin is responsible for the efflux of iodine through TFCs. NIS antibodies are found in 17-31\% of patients with ATD and in some cases these antibodies have a functional role in vitro by inhibiting the activity of the symporter [86-89]. Antibodies against 
pendrin are detected in only $9-11 \%$ of patients with ATD $[90,91]$. Although the frequency of NIS and pendrin antibodies is slightly lower in HT compared with GD, the marginal difference indicates that these antibodies are unlikely to determine disease presentation $[92,93]$.

\section{Thyroid stimulating hormone receptor (TSHR) antibodies} Antibodies against the TSHR receptor have a clear functional role in GD by stimulating receptor function (thyroid stimulating antibodies or TSAb). Less commonly, however, these antibodies possess blocking activity. The balance between TSAb and TBAb (thyroid blocking antibodies) can determine disease presentation (hyper- or hypothyroidism), which explains the fluctuating thyroid hormone levels in some patients with ATD. A number of factors can modulate the balance between TSAb and TBAb, including antithyroid drugs or thyroxine treatment and pregnancy [94]. In one unusual case reported recently, an 80 year old woman with long standing HT developed Graves' disease, with apparently de novo synthesis of TSAb and no evidence of TBAb [95]. Understanding how such freakish fluctuations in TSHR autoimmunity occur would provide useful insights into the pathogenesis of thyroid autoimmunity.

\section{The Role of Cytokines}

\section{$\nabla$}

This topic has been previously reviewed [96,97], and only a brief update is provided here. Cytokines were initially classified into those produced, in mice at least, by Th1 and Th2 T cell subsets, and are involved in cellular and humoral immune responses respectively. Later a third subset was added, called Th3 cells which mainly synthesise TGF $\beta$ and act as regulatory cells [98]. A more recent subset of Th17 cytokines was described, which includes IL-17 and IL-22, cytokines that are involved in the pathogenesis of chronic inflammatory conditions $[98,99]$. Although IL-22 is classified by some as a Th17 cytokine, others describe a distinct subpopulation of $\mathrm{T}$ helper cells that produce this cytokine, termed Th22 [99-102].

Studies have attempted to understand the type of cytokine response in ATD and a predominance of a Th1 response in HT has been demonstrated $[97,100]$. However, we should be cautious in our interpretations as surgery is unusual in HT and could be introducing a selection bias making general applicability of the results uncertain. Therefore, studies on peripheral blood cytokine levels may be more appropriate but these have their drawbacks in terms of sensitivity and specificity.

A study investigating IL-17 and IL-22 has shown increased plasma levels of these cytokines in ATD, particularly in patients with HT. This was associated with stronger expression of IL-17 and IL-22 in the thyroid gland of HT patients compared with GD or controls, suggesting a specific role for these cytokines in autoimmune hypothyroidism [101]. Production of IL-22 is promoted by IL- 6 and tumour necrosis factor- $\alpha$. Interestingly, peripheral T lymphocytes from HT patients show enhanced differentiation into Th22 cells following IL-6 stimulation in vitro. Moreover, IL-22 levels correlate with TPO antibody levels in patients with HT, suggesting a role for this cytokine in antibody production [102]. However, others have documented that IL-22 has a role in GD rather than HT pathogenesis [103]. Given these contradictory data further studies are warranted to clarify the role of IL-22 in HT.

IL-23, produced by cells of the innate immune response, is part of the IL-12 family promoting a Th1 response. IL-23 serum levels were higher in $81 \mathrm{HT}$ patients compared with 80 controls, although only $56 \%$ of HT patients had detectable levels of this cytokine [104]. IL-14 and IL-16 have also been studied, as these too are involved in humoral and cellular immune responses respectively. IL-14 and IL-16 gene expression was detected in almost all HT tissue samples but only a minority of MNG, suggesting a role for these cytokines in autoimmune hypothyroidism. However, the detection of IL-14 and IL-16 in GD tissue samples indicates that these cytokines are not HT-specific but more likely to play a role in the diverse spectrum of ATD (Kemp et al., manuscript under revision). On the other hand, recent work suggests that interferon $\gamma$ inducible protein 10 , produced by thyrocytes and immune cells, may be responsible for more severe tissue destruction in thyroid autoimmunity and further work is needed to investigate this possibility [105].

In addition to the effects of cytokines on infiltrating inflammatory cells, these molecules can modulate thyroid cell growth and function, and can even alter the immunological properties of these cells [97]. TFC integrity is compromised in HT, related, at least in part, to reduced expression of junction proteins, including ZO- 1 and JAM-A. In vitro studies have demonstrated that IL-1 $\beta$ can directly modulate junction protein expression, thus mediating TFC destruction in HT [106]. Cytokines can also reduce caveolin 1 production (part of the thyroxisome together with TPO and dual oxidase), thereby directly modulating thyroid hormone production [83].

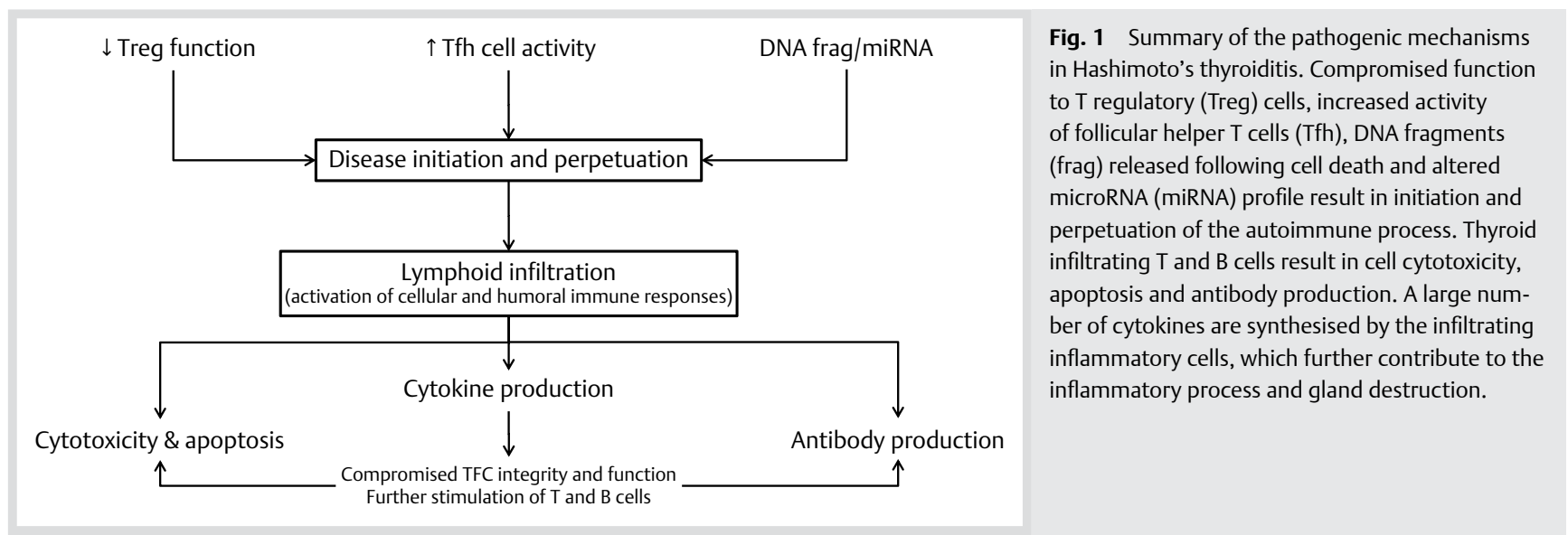




\section{DNA Fragments and Micro RNA}

$\sqrt{2}$

Previous work has shown that molecules released from dying or dead cells encourage the development of a sterile inflammatory milieu, which in turn activates the immune response [107]. More specifically, the release of genomic DNA has been shown to activate innate immunity [108]. In vitro thyroid cell injury and subsequent genomic DNA release was associated with the development of an inflammatory reaction and compromised function of key thyroid proteins including NIS [109]. In a series of elegant experiments, the investigators demonstrated that histone $\mathrm{H} 2 \mathrm{~B}$, which bound genomic DNA, was responsible for activation of innate immunity and therefore sterile thyroid injury appears to be enough to trigger thyroid autoimmunity.

MicroRNAs (miRNA), which are small noncoding RNA regions, have also been implicated in the pathogenesis of thyroid immunity. Various miRNA have been shown to control innate and adaptive immune responses [110]. In HT tissue, obtained using fine needle aspiration, miR-155_2 was found to be decreased, coupled with an increase in miR-200a 1 when compared with healthy control thyroid tissue [111]. In addition to tissue samples, serum miRNA was also tested with miR-22, miR-375 and miR-451 showing increased levels in both HT and GD patients compared with controls [112]. Further work in this area is required to understand the potential of miRNA as novel therapeutic targets in ATD in general and HT in particular.

The pathogenic mechanisms operating in HT are summarised in $\odot$ Fig. 1.

\section{Conflict of Interest}

The authors declare no conflict of interest.

\section{References}

1 Hashimoto $H$. Zur Kenntniss der lymphomatösen Veränderung der Schilddrüse (Struma lymphomatosa). Arch Lin Chir 1912; 97: 219248

2 Doniach D, Hudson RV. Lymphadenoid goitre (Hashimoto's disease); diagnostic and biochemical aspects. Br Med J 1957; 1: 672-678

3 Carle A, Pedersen IB, Knudsen N, Perrild $H$, Ovesen L, Jorgensen $T$, Laurberg $P$. Thyroid volume in hypothyroidism due to autoimmune disease follows a unimodal distribution: evidence against primary thyroid atrophy and autoimmune thyroiditis being distinct diseases. J Clin Endocrinol Metab 2009; 94: 833-839

4 Hiromatsu Y, Satoh H, Amino N. Hashimoto's thyroiditis: history and future outlook. Hormones (Athens) 2013; 12: 12-18

5 Weetman AP. The immunopathogenesis of chronic autoimmune thyroiditis one century after hashimoto. Eur Thyroid J 2013; 1: 243-250

6 Caturegli P, De RA, Rose NR. Hashimoto thyroiditis: clinical and diagnostic criteria. Autoimmun Rev 2014; 13: 391-397

7 Effraimidis G, Wiersinga WM. Mechanisms in endocrinology: autoimmune thyroid disease: old and new players. Eur J Endocrinol 2014; 170: R241-R252

8 McLeod DS, Caturegli P, Cooper DS, Matos PG, Hutfless S. Variation in rates of autoimmune thyroid disease by race/ethnicity in US military personnel. JAMA 2014; 311: 1563-1565

9 Wiebolt J, Achterbergh R, den BA, van der Leij S, Marsch E, Suelmann $B$, de VR, van Haeften TW. Clustering of additional autoimmunity behaves differently in Hashimoto's patients compared with Graves' patients. Eur J Endocrinol 2011; 164: 789-794

10 Hou X, Li Y, Li J, Wang W, Fan C, Wang H, Zhang H, Shan Z, Teng W. Development of thyroid dysfunction and autoantibodies in Graves' multiplex families: an eight-year follow-up study in Chinese Han pedigrees. Thyroid 2011; 21: 1353-1358
11 Brix TH, Hegedus L, Gardas A, Banga JP, Nielsen CH. Monozygotic twin pairs discordant for Hashimoto's thyroiditis share a high proportion of thyroid peroxidase autoantibodies to the immunodominant region A. Further evidence for genetic transmission of epitopic "fingerprints". Autoimmunity 2011; 44: 188-194

12 Outschoorn IM, Talor MV, Burek CL, Hoffman WH, Rose NR. Heritability analysis of IgG4 antibodies in autoimmune thyroid disease. Autoimmunity 2014; 47: 320-326

13 Huang CY, Chang TY, Chu CC, Lo FS, Ting WH, Lin CH, Wu YL, Chu SY, Chang SC, Chen WF, Lin CL, Lin WS, Lee YJ. The HLA-B gene and Hashimoto disease in Han Chinese children: a case-control and familybased study. Tissue Antigens 2012; 80: 431-436

14 Ueda S, Oryoji D, Yamamoto K, Noh JY, Okamura K, Noda M, Kashiwase $K$, Kosuga $Y$, Sekiya $K$, Inoue $K$, Yamada $H$, Oyamada A, Nishimura $Y$, Yoshikai Y, Ito K, Sasazuki T. Identification of independent susceptible and protective HLA alleles in Japanese autoimmune thyroid disease and their epistasis. J Clin Endocrinol Metab 2014; 99: E379-E383

15 Bernecker C, Ostapczuk M, Vordenbaumen S, Ehlers M, Thiel A, Schinner $S$, Willenberg H, Scherbaum WA, Schott M. HLA-A2 phenotype may be protective against Graves' disease but not against Hashimoto's thyroiditis in Caucasians. Horm Metab Res 2013; 45: 74-77

16 Ji R, Feng $Y$, Zhan $W W$. Updated analysis of studies on the cytotoxic T-lymphocyte-associated antigen-4 gene A49G polymorphism and Hashimoto's thyroiditis risk. Genet Mol Res 2013; 12: 1421-1430

17 Luo L, Cai B, Liu F, Hu X, Wang L. Association of Protein Tyrosine Phosphatase Nonreceptor 22 (PTPN22) C1858T gene polymorphism with susceptibility to autoimmune thyroid diseases: a meta-analysis. Endocr J 2012; 59: 439-445

18 Li M, Sun H, Liu S, Yu J, Li Q Liu P, Shen H, Sun D. CD40 C/T-1 polymorphism plays different roles in Graves' disease and Hashimoto's thyroiditis: a meta-analysis. Endocr J 2012; 59: 1041-1050

19 Zaaber I, Mestiri S, Marmouch H, Mahjoub S, Abid N, Hassine M, Bel $H \mathrm{Jr}$, Said $\mathrm{K}$. Polymorphisms in TSHR and IL1RN genes and the risk and prognosis of Hashimoto's thyroiditis. Autoimmunity 2014; 47: 113-118

20 Yan N, Yu YL, Yang J, Qin Q, Zhu YF, Wang X, Song RH, Zhang JA. Association of interleukin-17A and -17F gene single-nucleotide polymorphisms with autoimmune thyroid diseases. Autoimmunity 2012; 45 : 533-539

21 Walsh JP, Berry J, Liu S, Panicker V, Dayan CM, Brix TH, Hegedus L, Hou $P$, Shi $B$, Morahan $G$. The clinical presentation of autoimmune thyroid disease in men is associated with IL12B genotype. Clin Endocrinol (Oxf) 2011; 74: 508-512

22 Inoue N, Watanabe M, Morita M, Tatusmi K, Hidaka Y, Akamizu T, Iwatani $Y$. Association of functional polymorphisms in promoter regions of IL5, IL6 and IL13 genes with development and prognosis of autoimmune thyroid diseases. Clin Exp Immunol 2011; 163: 318-323

23 Tomizawa R, Watanabe M, Inoue N, Takemura K, Hidaka Y, Akamizu $T$, Hayakawa K, Iwatani Y. Association of functional GITR gene polymorphisms related to expression of glucocorticoid-induced tumour necrosis factor-receptor (GITR) molecules with prognosis of autoimmune thyroid disease. Clin Exp Immunol 2011; 165: 141-147

24 Xiao L, Muhali FS, Cai TT, Song RH, Hu R, Shi XH, Jiang WJ, Li DF, He $S T$, Xu J, Zhang JA. Association of single-nucleotide polymorphisms in the STAT3 gene with autoimmune thyroid disease in Chinese individuals. Funct Integr Genomics 2013; 13: 455-461

25 Ban $Y$, Tozaki T, Taniyama M, Skrabanek L, Nakano $Y$, Ban $Y$, Hirano $T$. Multiple SNPs in intron 41 of thyroglobulin gene are associated with autoimmune thyroid disease in the Japanese population. PLoS One 2012; 7: e37501

26 Stefan M, Jacobson EM, Huber AK, Greenberg DA, Li CW, Skrabanek L, Conception E, Fadlalla M, Ho K, Tomer Y. Novel variant of thyroglobulin promoter triggers thyroid autoimmunity through an epigenetic interferon alpha-modulated mechanism. J Biol Chem 2011; 286: 31168-31179

27 Santos LR, Duraes C, Mendes A, Prazeres H, Alvelos MI, Moreira CS, Canedo P, Esteves C, Neves C, Carvalho D, Sobrinho-Simoes $M$, Soares $P$. A polymorphism in the promoter region of the selenoprotein $S$ gene (SEPS1) contributes to Hashimoto's thyroiditis susceptibility. J Clin Endocrinol Metab 2014; 99: E719-E723

28 Simmonds MJ. GWAS in autoimmune thyroid disease: redefining our understanding of pathogenesis. Nat Rev Endocrinol 2013; 9: 277-287 
29 Medici M, Porcu E, Pistis G, Teumer A, Brown SJ, Jensen RA, Rawal R, Roef GL, Plantinga TS, Vermeulen SH, Lahti J, Simmonds MJ, Husemoen $L L$, Freathy RM, Shields BM, Pietzner D, Nagy R, Broer L, Chaker $L$, Korevaar TI, Plia MG, Sala C, Volker U, Richards JB, Sweep FC, Gieger C, Corre T, Kajantie E, Thuesen B, Taes YE, Visser WE, Hattersley AT, Kratzsch J, Hamilton A, Li W, Homuth G, Lobina M, Mariotti S, Soranzo $N$, Cocca M, Nauck M, Spielhagen C, Ross A, Arnold A, van de Bunt M, Liyanarachchi S, Heier M, Grabe HJ, Masciullo C, Galesloot TE, Lim EM, Reischl E, Leedman PJ, Lai S, Delitala A, Bremner AP, Philips DI, Beilby $J P$, Mulas A, Vocale M, Abecasis G, Forsen T, James A, Widen E, Hui J, Prokisch H, Rietzschel EE, Palotie A, Feddema P, Fletcher SJ, Schramm $K$, Rotter JI, Kluttig A, Radke D, Traglia M, Surdulescu GL, He H, Franklyn JA, Tiller D, Vaidya B, de MT, Jorgensen T, Eriksson JG, O'Leary PC, Wichmann E, Hermus AR, Psaty BM, Ittermann T, Hofman A, Bosi E, Schlessinger D, Wallaschofski $H$, Pirastu N, Aulchenko YS, de la Chapelle A, Netea-Maier RT, Gough SC, Meyer Zu SH, Frayling TM, Kaufman JM, Linneberg A, Raikkonen K, Smit JW, Kiemeney LA, Rivadeneira F, Uitterlinden AG, Walsh JP, Meisinger C, den HM, Visser TJ, Spector TD, Wilson SG, Volzke H, Cappola A, Toniolo D, Sanna S, Naitza S, Peeters $R P$. Identification of novel genetic Loci associated with thyroid peroxidase antibodies and clinical thyroid disease. PLoS Genet 2014; 10 : e1004123

30 Cooper JD, Simmonds MJ, Walker NM, Burren O, Brand OJ, Guo H, Wallace C, Stevens H, Coleman G, Franklyn JA, Todd JA, Gough SC. Seven newly identified loci for autoimmune thyroid disease. Hum Mol Genet 2012; 21: 5202-5208

31 Tomer Y, Hasham A, Davies TF, Stefan M, Concepcion E, Keddache M, Greenberg DA. Fine mapping of loci linked to autoimmune thyroid disease identifies novel susceptibility genes. J Clin Endocrinol Metab 2013; 98: E144-E152

32 Caturegli P, De RA, Chuang K, Dembele M, Iwama A, Iwama S. Hashimoto's thyroiditis: celebrating the centennial through the lens of the Johns Hopkins hospital surgical pathology records. Thyroid 2013; 23: $142-150$

33 Ott J, Meusel M, Schultheis A, Promberger R, Pallikunnel SJ, Neuhold N, Hermann $M$. The incidence of lymphocytic thyroid infiltration and Hashimoto's thyroiditis increased in patients operated for benign goiter over a 31-year period. Virchows Arch 2011; 459: 277-281

34 Kondrashova A, Seiskari T, Ilonen J, Knip M, Hyoty H. The Hygiene 'hypothesis' and the sharp gradient in the incidence of autoimmune and allergic diseases between Russian Karelia and Finland. APMIS 2013; 121: 478-493

35 Aghini LF, Fiore E, Tonacchera M, Antonangeli L, Rago T, Frigeri $M$, Provenzale AM, Montanelli L, Grasso L, Pinchera A, Vitti P. The effect of voluntary iodine prophylaxis in a small rural community: the Pescopagano survey 15 years later. J Clin Endocrinol Metab 2013; 98: 1031-1039

36 Toulis KA, Anastasilakis AD, Tzellos TG, Goulis DG, Kouvelas D. Selenium supplementation in the treatment of Hashimoto's thyroiditis: a systematic review and a meta-analysis. Thyroid 2010; 20: 11631173

37 van Zuuren EJ, Albusta AY, Fedorowicz Z, Carter B, Pijl H. Selenium Supplementation for Hashimoto's Thyroiditis: Summary of a Cochrane Systematic Review. Eur Thyroid J 2014; 3: 25-31

38 Winther KH, Watt T, Bjørner JB, Cramon P, Feldt-Rasmussen U, Gluud C, Gram J, Groenvold $M$, Hegedüs L, Knudsen N, Rasmussen ÅK, Bonnema SJ. The chronic autoimmune thyroiditis quality of life selenium trial (CATALYST): study protocol for a randomized controlled trial. Trials 2014; 15: 115-126

39 Tamer G, Arik S, Tamer I, Coksert D. Relative vitamin D insufficiency in Hashimoto's thyroiditis. Thyroid 2011; 21: 891-896

40 D'Aurizio F, Villalta D, Metus P, Doretto P, Tozzoli $R$. Is vitamin D a player or not in the pathophysiology of autoimmune thyroid diseases? Autoimmun Rev 2014, Oct 12. pii: S1568-9972(14)00220-1 doi:10.1016/j.autrev.2014.10.008 [Epub ahead of print]

41 Torino F, Barnabei A, Paragliola R, Baldelli R, Appetecchia M, Corsello $S M$. Thyroid dysfunction as an unintended side effect of anticancer drugs. Thyroid 2013; 23: 1345-1366

42 Hasham A, Zhang $W$, Lotay $V$, Haggerty S, Stefan M, Concepcion E, Dieterich DT, Tomer Y. Genetic analysis of interferon induced thyroiditis (IIT): evidence for a key role for MHC and apoptosis related genes and pathways. J Autoimmun 2013; 44: 61-70

43 Weetman A. Immune reconstitution syndrome and the thyroid. Best Pract Res Clin Endocrinol Metab 2009; 23: 693-702

44 Daniels GH, Vladic A, Brinar V, Zavalishin I, Valente W, Oyuela P, Palmer $J$, Margolin DH, Hollenstein J. Alemtuzumab-related thyroid dysfunction in a phase 2 trial of patients with relapsing-remitting multiple sclerosis. J Clin Endocrinol Metab 2014; 99: 80-89
45 Visser $R$, de MQ Netea-Maier RT, van der Ven AJ. Hashimoto's thyroiditis presenting as acute painful thyroiditis and as a manifestation of an immune reconstitution inflammatory syndrome in a human immunodeficiency virus-seropositive patient. Thyroid 2012; 22: 853-855

46 Carle A, Bulow PI, Knudsen N, Perrild H, Ovesen L, Banke RL, Jorgensen T, Laurberg P. Smoking cessation is followed by a sharp but transient rise in the incidence of overt autoimmune hypothyroidism - a populationbased, case-control study. Clin Endocrinol (Oxf) 2012; 77: 764-772

47 Effraimidis G, Strieder TG, Tijssen JG, Wiersinga WM. Natural history of the transition from euthyroidism to overt autoimmune hypo- or hyperthyroidism: a prospective study. Eur J Endocrinol 2011; 164: 107-113

48 Carle A, Pedersen IB, Knudsen N, Perrild H, Ovesen L, Rasmussen LB, Jorgensen $T$, Laurberg $P$. Moderate alcohol consumption may protect against overt autoimmune hypothyroidism: a population-based case-control study. Eur J Endocrinol 2012; 167: 483-490

49 Effraimidis G, Tijssen JG, Wiersinga WM. Alcohol consumption as a risk factor for autoimmune thyroid disease: a prospective study. Eur Thyroid J 2012; 1: 99-104

50 Caselli E, Zatelli MC, Rizzo R, Benedetti S, Martorelli D, Trasforini G, Cassai E, degli Uberti EC, Di LD, Dolcetti R. Virologic and immunologic evidence supporting an association between HHV-6 and Hashimoto's thyroiditis. PLoS Pathog 2012; 8: e1002951

51 Effraimidis G, Tijssen JG, Strieder TG, Wiersinga WM. No causal relationship between Yersinia enterocolitica infection and autoimmune thyroid disease: evidence from a prospective study. Clin Exp Immunol 2011; 165: 38-43

52 Goldner WS, Sandler DP, Yu F, Hoppin JA, Kamel F, Levan TD. Pesticide use and thyroid disease among women in the Agricultural Health Study. Am J Epidemiol 2010; 171: 455-464

53 de Freitas CU, Grimaldi Campos RA, Rodrigues Silva MA, Panachao MR, de Moraes JC, Waissmann W, Roberto CA, Maeda MY, Minazzi Rodrigues RS, Goncalves BJ, Oliveira BS, Santos RT. Can living in the surroundings of a petrochemical complex be a risk factor for autoimmune thyroid disease? Environ Res 2010; 110: 112-117

54 Lee TP, Chiang BL. Sex differences in spontaneous versus induced animal models of autoimmunity. Autoimmun Rev 2012; 11: A422-A429

55 Brix TH, Hansen PS, Kyvik KO, Hegedüs L. Aggregation of thyroid autoantibodies in twins from opposite-sex pairs suggests that microchimerism may play a role in the early stages of thyroid autoimmunity. J Clin Endocrinol Metab 2009; 94: 4439-4443

56 Simmonds MJ, Kavvoura FK, Brand OJ, Newby PR, Jackson LE, Hargreaves CE, Franklyn JA, Gough SC. Skewed X chromosome inactivation and female preponderance in autoimmune thyroid disease: an association study and meta-analysis. J Clin Endocrinol Metab 2014; 99: E127-E131

57 Lepez T, Vandewoestyne M, Hussain S, Van NF, Poppe K, Velkeniers B, Kaufman JM, Deforce D. Fetal microchimeric cells in blood of women with an autoimmune thyroid disease. PLoS One 2011; 6: e29646

58 Greer LG, Casey BM, Halvorson LM, Spong CY, McIntire DD, Cunningham FG. Antithyroid antibodies and parity: further evidence for microchimerism in autoimmune thyroid disease. Am J Obstet Gynecol 2011; 205: 471-474

59 Jorgensen KT, Pedersen BV, Nielsen NM, Jacobsen S, Frisch M. Childbirths and risk of female predominant and other autoimmune diseases in a population-based Danish cohort. J Autoimmun 2012; 38: J81-J87

60 Weetman AP. Immunity, thyroid function and pregnancy: molecular mechanisms. Nat Rev Endocrinol 2010; 6: 311-318

61 Effraimidis G, Tijssen JG, Brosschot JF, Wiersinga WM. Involvement of stress in the pathogenesis of autoimmune thyroid disease: a prospective study. Psychoneuroendocrinology 2012; 37: 1191-1198

62 Hamilton A, Newby PR, Carr-Smith JD, Disanto G, Allahabadia A, Armitage $M$, Brix TH, Chatterjee K, Connell JM, Hegedus L, Hunt PJ, Lazarus JH, Pearce SH, Robinson BG, Taylor JC, Vaidya B, Wass JA, Wiersinga WM, Weetman AP, Ramagopalan SV, Franklyn JA, Gough SC, Simmonds $M J$. Impact of month of birth on the development of autoimmune thyroid disease in the United Kingdom and Europe. J Clin Endocrinol Metab 2014; 99: E1459-E1465

63 Cepon TJ, Snodgrass JJ, Leonard WR, Tarskaia LA, Klimova TM, Fedorova VI, Baltakhinova ME, Krivoshapkin VG. Circumpolar adaptation, social change, and the development of autoimmune thyroid disorders among the Yakut (Sakha) of Siberia. Am J Hum Biol 2011; 23: 703-709

64 Volpe $R$. Suppressor T lymphocyte dysfunction is important in the pathogenesis of autoimmune thyroid disease: a perspective. Thyroid 1993; 3: 345-352

65 MacDonald TT. Suppressor T cells, rebranded as regulatory T cells, emerge from the wilderness bearing surface markers. Gut 2002; 51: 311-312 
66 Fehervari Z, Sakaguchi S. CD4+ Tregs and immune control. J Clin Invest 2004; 114: 1209-1217

67 Piccirillo CA. Regulatory T cells in health and disease. Cytokine 2008; 43: 395-401

68 Tang $Q$, Bluestone JA. The Foxp3 + regulatory T cell: a jack of all trades, master of regulation. Nat Immunol 2008; 9: 239-244

69 Shevach EM. Suppressor T cells: Rebirth, function and homeostasis. Curr Biol 2000; 10: R572-R575

70 Pan D, Shin YH, Gopalakrishnan G, Hennessey J, De Groot LJ. Regulatory T cells in Graves' disease. Clin Endocrinol (Oxf) 2009; 71: 587-593

71 Wang $H$, Zhao S, Tang X, Li J, Zou P. Changes of regulatory T cells in Graves' disease. J Huazhong Univ Sci Technolog Med Sci 2006; 26 : 545-547

72 Marazuela $M$, Garcia-Lopez MA, Figueroa-Vega $N$, de la Fuente $H$, Alvarado-Sanchez B, Monsivais-Urenda A, Sanchez-Madrid F, Gonzalez-Amaro $R$. Regulatory $T$ cells in human autoimmune thyroid disease. J Clin Endocrinol Metab 2006; 91: 3639-3646

73 Mao C, Wang S, Xiao Y, Xu J, Jiang Q, Jin M, Jiang X, Guo H, Ning G, Zhang $Y$. Impairment of regulatory capacity of CD4+CD25+ regulatory $T$ cells mediated by dendritic cell polarization and hyperthyroidism in Graves' disease. J Immunol 2011; 186: 4734-4743

74 Glick $A B$, Wodzinski $A, F u P$, Levine $A D$, Wald $D N$. Impairment of regulatory $\mathrm{T}$-cell function in autoimmune thyroid disease. Thyroid 2013: 23: 871-878

75 Mirandola P, Gobbi G, Masselli E, Micheloni C, Di MD, Queirolo V, Chiodera $P$, Meschi $T$, Vitale $M$. Protein kinase Cepsilon regulates proliferation and cell sensitivity to TGF-1beta of CD4 + T lymphocytes: implications for Hashimoto thyroiditis. J Immunol 2011; 187: 4721-4732

76 Spolski R, Leonard WJ. IL-21 and T follicular helper cells. Int Immunol 2010; 22: 7-12

77 Zhu C, Ma J, Liu Y, Tong J, Tian J, Chen J, Tang X, Xu H, Lu L, Wang S. Increased frequency of follicular helper T cells in patients with autoimmune thyroid disease. J Clin Endocrinol Metab 2012; 97: 943-950

78 Ehlers M, Thiel A, Bernecker C, Porwol D, Papewalis C, Willenberg HS, Schinner S, Hautzel H, Scherbaum WA, Schott M. Evidence of a combined cytotoxic thyroglobulin and thyroperoxidase epitope-specific cellular immunity in Hashimoto's thyroiditis. J Clin Endocrinol Metab 2012; 97: 1347-1354

79 Wong $C P$, Stevens $R$, Long B, Li L, Wang Y, Wallet MA, Goudy KS, Frelinger JA, Tisch $R$. Identical beta cell-specific CD8(+) T cell clonotypes typically reside in both peripheral blood lymphocyte and pancreatic islets. J Immunol 2007; 178: 1388-1395

80 Kotani T, Aratake Y, Hirai K, Fukazawa Y, Sato H, Ohtaki S. Apoptosis in thyroid tissue from patients with Hashimoto's thyroiditis. Autoimmunity 1995; 20: 231-236

81 Baker JR Jr. Dying (apoptosing?) for a consensus on the Fas death pathway in the thyroid. J Clin Endocrinol Metab 1999; 84: 2593-2595

82 Kaczmarek E, Lacka K, Jarmolowska-Jurczyszyn D, Sidor A, Majewski $P$. Changes of $B$ and $T$ lymphocytes and selected apopotosis markers in Hashimoto's thyroiditis. J Clin Pathol 2011; 64: 626-630

83 Marique L, Van RV, Gerard AC, Craps J, Senou M, Marbaix E, Rahier J, Daumerie C, Mourad M, Lengele B, Colin IM, Many MC. The expression of dual oxidase, thyroid peroxidase, and caveolin-1 differs according to the type of immune response (TH1/TH2) involved in thyroid autoimmune disorders. J Clin Endocrinol Metab 2014; 99: 1722-1732

84 Weetman AP. Cellular immune responses in autoimmune thyroid disease. Clin Endocrinol (Oxf) 2004; 61: 405-413

85 Walsh JP, Bremner AP, Feddema P, Leedman PJ, Brown SJ, O'Leary P. Thyrotropin and thyroid antibodies as predictors of hypothyroidism: a 13-year, longitudinal study of a community-based cohort using current immunoassay techniques. J Clin Endocrinol Metab 2010; 95: 1095-1104

86 Hamano H, Kawa S, Horiuchi A, Unno H, Furuya N, Akamatsu T, Fukushima $M$, Nikaido T, Nakayama K, Usuda N, Kiyosawa K. High serum IgG4 concentrations in patients with sclerosing pancreatitis. $\mathrm{N}$ Engl J Med 2001; 344: 732-738

87 Li Y, Nishihara E, Hirokawa M, Taniguchi E, Miyauchi A, Kakudo K. Distinct clinical, serological, and sonographic characteristics of hashimoto's thyroiditis based with and without IgG4-positive plasma cells. J Clin Endocrinol Metab 2010; 95: 1309-1317

88 Kakudo K, Li Y, Hirokawa M, Ozaki T. Diagnosis of Hashimoto's thyroiditis and IgG4-related sclerosing disease. Pathol Int 2011; 61: 175-183

89 Dahlgren M, Khosroshahi A, Nielsen GP, Deshpande V, Stone JH. Riedel's thyroiditis and multifocal fibrosclerosis are part of the IgG4-related systemic disease spectrum. Arthritis Care Res (Hoboken) 2010; 62: $1312-1318$
90 Kemp EH, Sandhu HK, Watson PF, Weetman AP. Low frequency of pendrin autoantibodies detected using a radioligand binding assay in patients with autoimmune thyroid disease. J Clin Endocrinol Metab 2013; 98: E309-E313

91 Brix TH, Hegedus L, Weetman AP, Kemp HE. Pendrin and NIS antibodies are absent in healthy individuals and are rare in autoimmune thyroid disease: evidence from a Danish twin study. Clin Endocrinol (Oxf) 2014; 81: 440-444

92 Ajjan RA, Kemp EH, Waterman EA, Watson PF, Endo T, Onaya T, Weetman AP. Detection of binding and blocking autoantibodies to the human sodium-iodide symporter in patients with autoimmune thyroid disease. J Clin Endocrinol Metab 2000; 85: 2020-2027

93 Ajjan RA, Findlay C, Metcalfe RA, Watson PF, Crisp M, Ludgate M, Weetman $A P$. The modulation of the human sodium iodide symporter activity by Graves' disease sera. J Clin Endocrinol Metab 1998; 83: 1217-1221

94 McLachlan SM, Rapoport B. Thyrotropin-blocking autoantibodies and thyroid-stimulating autoantibodies: potential mechanisms involved in the pendulum swinging from hypothyroidism to hyperthyroidism or vice versa. Thyroid 2013; 23: 14-24

95 Kamath C, Young S, Kabelis K, Sanders J, Adlan MA, Furmaniak J, Rees Smith $B$, Premawardhana $L D$. Thyrotrophin receptor antibody characteristics in a woman with long-standing Hashimoto's who developed Graves' disease and pretibial myxoedema. Clin Endocrinol (Oxf) 2012; 77: 465-470

96 Lumachi F, Basso SM, Orlando R. Cytokines thyroid diseases and thyroid cancer. Cytokine 2010; 50: 229-233

97 Ajjan RA, Weetman AP. Cytokines in thyroid autoimmunity. Autoimmunity 2003; 36: 351-359

98 Bettelli E, Korn T, Kuchroo VK. Th17: the third member of the effector T cell trilogy. Curr Opin Immunol 2007; 19: 652-657

99 Pan HF, Li XP, Zheng SG, Ye DQ. Emerging role of interleukin-22 in autoimmune diseases. Cytokine Growth Factor Rev 2013; 24: 51-57

100 Trifari S, Kaplan CD, Tran EH, Crellin NK, Spits $H$. Identification of a human helper $\mathrm{T}$ cell population that has abundant production of interleukin 22 and is distinct from $\mathrm{T}(\mathrm{H})-17, \mathrm{~T}(\mathrm{H}) 1$ and $\mathrm{T}(\mathrm{H}) 2$ cells. Nat Immunol 2009; 10: 864-871

101 Figueroa-Vega N, Alfonso-Perez M, Benedicto I, Sanchez-Madrid F Gonzalez-Amaro $R$, Marazuela $M$. Increased circulating pro-inflammatory cytokines and Th17 lymphocytes in Hashimoto's thyroiditis. J Clin Endocrinol Metab 2010; 95: 953-962

102 Bai X, Sun J, Wang W, Shan Z, Zheng H, Li Y, Zhao Y, Gong M, Teng W. Increased differentiation of Th22 cells in Hashimoto's thyroiditis. Endocr J 2014

103 Song RH, Yu ZY, Qin Q, Wang X, Muhali FS, Shi LF, Jiang WJ, Xiao L, Li $D F$, Zhang JA. Different levels of circulating Th22 cell and its related molecules in Graves' disease and Hashimoto's thyroiditis. Int J Clin Exp Pathol 2014; 7: 4024-4031

104 Ruggeri RM, Saitta S, Cristani M, Giovinazzo S, Tigano V, Trimarchi F, Benvenga S, Gangemi S. Serum interleukin-23 (IL-23) is increased in Hashimoto's thyroiditis. Endocr J 2014; 61: 359-363

105 Ruffilli I, Ferrari SM, Colaci M, Ferri C, Fallahi P, Antonelli A. IP-10 in autoimmune thyroid disease. Horm Metab Res 2014; 46: 597-602

106 Rebuffat SA, Kammoun-Krichen M, Charfeddine I, Ayadi $H$, BougachaElleuch N, Peraldi-Roux S. IL-1beta and TSH disturb thyroid epithelium integrity in autoimmune thyroid diseases. Immunobiology 2013; 218: 285-291

107 Kono H, Rock KL. How dying cells alert the immune system to danger. Nat Rev Immunol 2008; 8: 279-289

108 Ishii KJ, Suzuki K, Coban C, Takeshita F, Itoh Y, Matoba H, Kohn LD, Klinman DM. Genomic DNA released by dying cells induces the maturation of APCs. J Immunol 2001; 167: 2602-2607

109 Kawashima A, Tanigawa K, Akama T, Wu H, Sue M, Yoshihara A, Ishido Y, Kobiyama K, Takeshita F, Ishii KJ, Hirano H, Kimura H, Sakai T, Ishii $N$, Suzuki K. Fragments of genomic DNA released by injured cells activate innate immunity and suppress endocrine function in the thyroid. Endocrinology 2011; 152: 1702-1712

110 Xiao C, Rajewsky K. MicroRNA control in the immune system: basic principles. Cell 2009; 136: 26-36

111 Bernecker C, Lenz L, Ostapczuk MS, Schinner S, Willenberg $H$, Ehlers $M$ Vordenbaumen S, Feldkamp J, Schott M. MicroRNAs miR-146a1, miR155_2, and miR-200a1 are regulated in autoimmune thyroid diseases. Thyroid 2012; 22: 1294-1295

112 Yamada $H$, Itoh $M$, Hiratsuka I, Hashimoto $S$. Circulating microRNAs in autoimmune thyroid diseases. Clin Endocrinol (Oxf) 2014; 81: 276-281 